\title{
THE ANALYSIS OF SYNCHRONOUS BLADE VIBRATION USING LINEAR SINE FITTING
}

\section{ANALIZA DRGAŃ SYNCHRONICZNYCH LOPATEK Z WYKORZYSTANIEM LINIOWEGO DOPASOWANIA FUNKCJI SINUS}

\author{
Radosław Przysowa \\ Instytut Techniczny Wojsk Lotniczych \\ e-mail: radoslaw.przysowa@itwl.pl
}

\begin{abstract}
In Blade Tip Timing several sensors installed circumferentially in the casing are used to record times of arrival (TOA) and observe deflections of blade tips. This paper aims to demonstrate methodology of model-based processing of aliased data. It focuses on the blade vibration excited by the forces synchronous with engine rotation, which are called integral responses. The driven harmonic oscillator with single degree of freedom (SDOF) is used to analyse blade vibration measured by tip-timing sensors during engine deceleration. When integral engine order EO is known, the linear sine fitting techniques can be used to process data from sensors to estimate amplitude, phase and frequency of blade vibration in each rotation. The oscillator model is implemented in MATLAB and used to generate resonance curves and simulate blade responses observed with tip sensors, installed in the axial compressor. Generated TOA data are fitted to the sine function to estimate vibration parameters. The validated procedure is then employed to analyze real test data.
\end{abstract}

Keywords: turbomachinery, blade vibration, tip-timing, sine fitting, least squares, harmonic oscillator

Streszczenie: W metodzie dyskretno-fazowej (ang. tip-timing) kilka czujników zamocowanych na obwodzie $w$ korpusie maszyny wirnikowej jest używanych do pomiaru czasów przyjścia i obserwacji odksztatceń wierzchotków topatek wirnika. $W$ artykule przedstawiono metodyki przetwarzania rzadko próbkowanych danych pomiarowych $z$ wykorzystaniem modelu matematycznego. Skoncentrowano się na drganiach topatek wymuszanych przez sity synchroniczne z obrotami wirnika.

Wymuszony oscylator harmoniczny, o jednym stopniu swobody, zostat wykorzystany do analizy drgań topatek mierzonych przez czujniki podczas deceleracji silnika. Jeśli znana jest rzędowość wymuszenia, liniowe techniki dopasowania funkcji sinus moga być używane do przetwarzania danych $w$ celu estymacji amplitudy, fazy i czesstotliwości drgań topatek $w$ kolejnych obrotach wirnika. Generowane czasy przyjścia dopasowywane sa do funkcji sinus $w$ celu estymacji parametrów drgań. Zweryfikowana $w$ ten sposób procedura jest następnie wykorzystana do analizy danych z rzeczywistych testów silnika.

Stowa kluczowe: przephywowe maszyny wirnikowe, drgania topatek, metoda dyskretno-fazowa, dopasowanie funkcji sinus, metoda najmniejszych kwadratów, oscylator harmoniczny 
The analysis of synchronous blade vibration using linear sine fitting Analiza drgań synchronicznych topatek z wykorzystaniem liniowego dopasowania..

\section{Driven harmonic oscillator and resonance curves}

A vibrating blade can be modelled as a single degree of freedom system. Forced vibration of blade tip is described by the equation of motion:

$$
\ddot{y}+\delta \dot{y}+\omega_{0}^{2} y=F_{0} \cos \omega t
$$

with the following solution:

$$
y=A \cos (\omega t+\varphi)
$$

The amplitude and phase of vibration depends on the frequency of vibration and damping factor $\delta$ :

$$
\begin{gathered}
A=\frac{F_{0}}{\sqrt{\left(\omega_{0}^{2}-\omega^{2}\right)^{2}+\delta^{2} \omega^{2}}} \\
\operatorname{tg} \varphi=\frac{\delta \omega}{\omega_{0}^{2}-\omega^{2}}
\end{gathered}
$$

Resonance curves shown on fig. 1-2 were generated for selected damping factors $\delta$ with the following script:

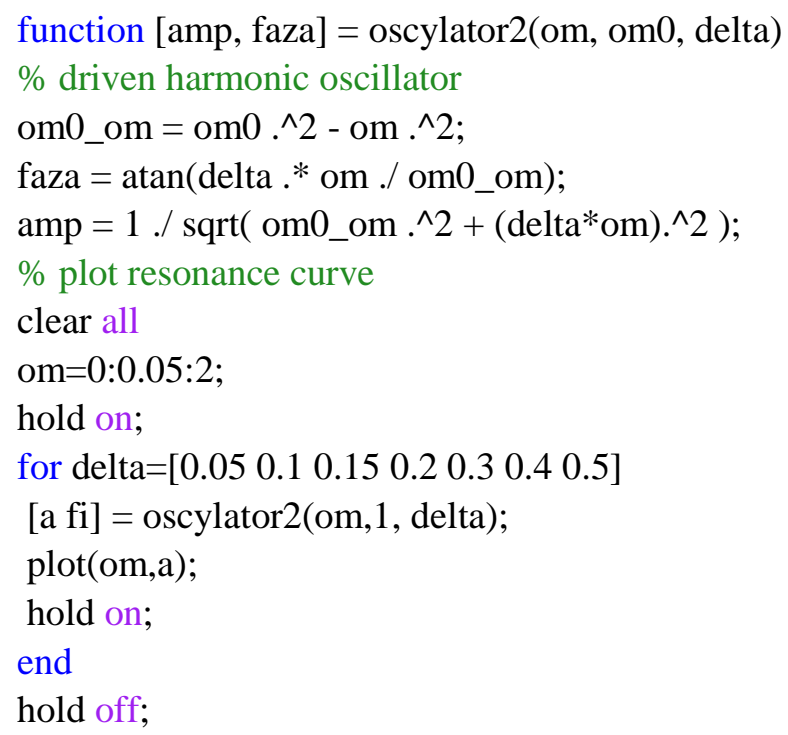

Typical blades are characterized by low damping factors $\delta<0.2$. In this case amplitude reaches maximum values at a frequency of excitation close to natural [14]. It is assumed that the highest tip deflection is observed at the resonance speed. 
Radostaw Przysowa

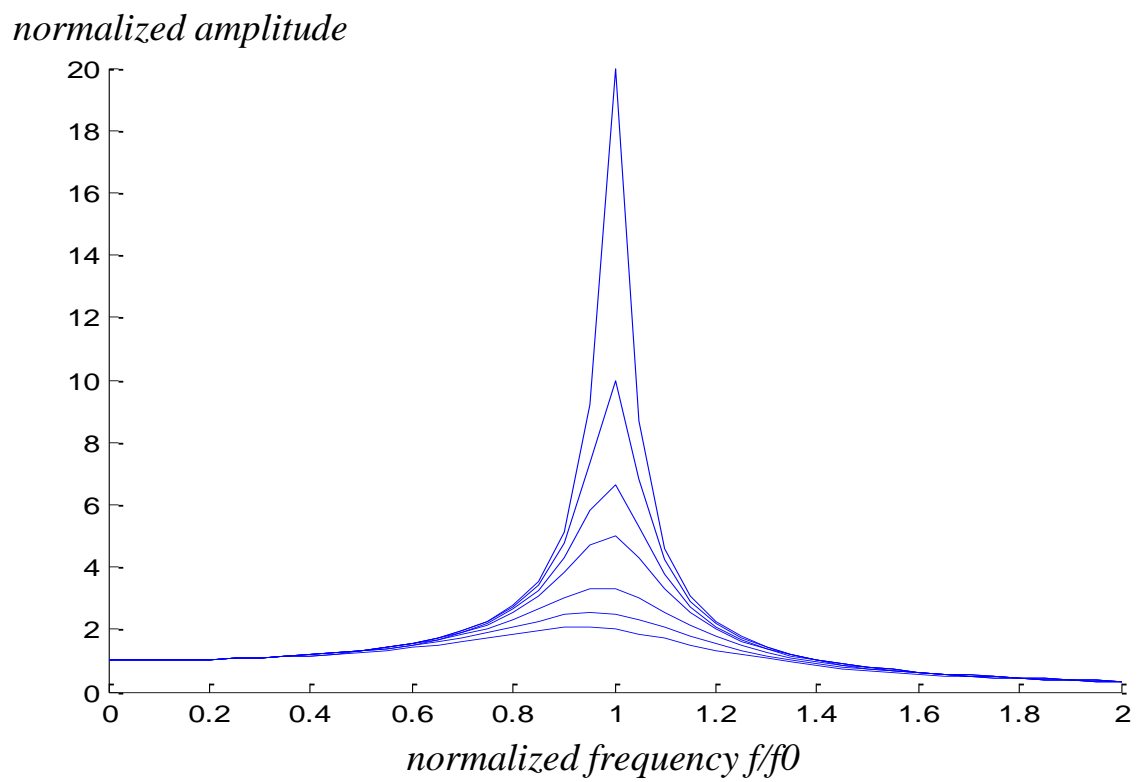

Fig.1 Resonance curves generated for selected damping factors $0.05,0.1,0.15,0.2,0.3,0.4,0.5$

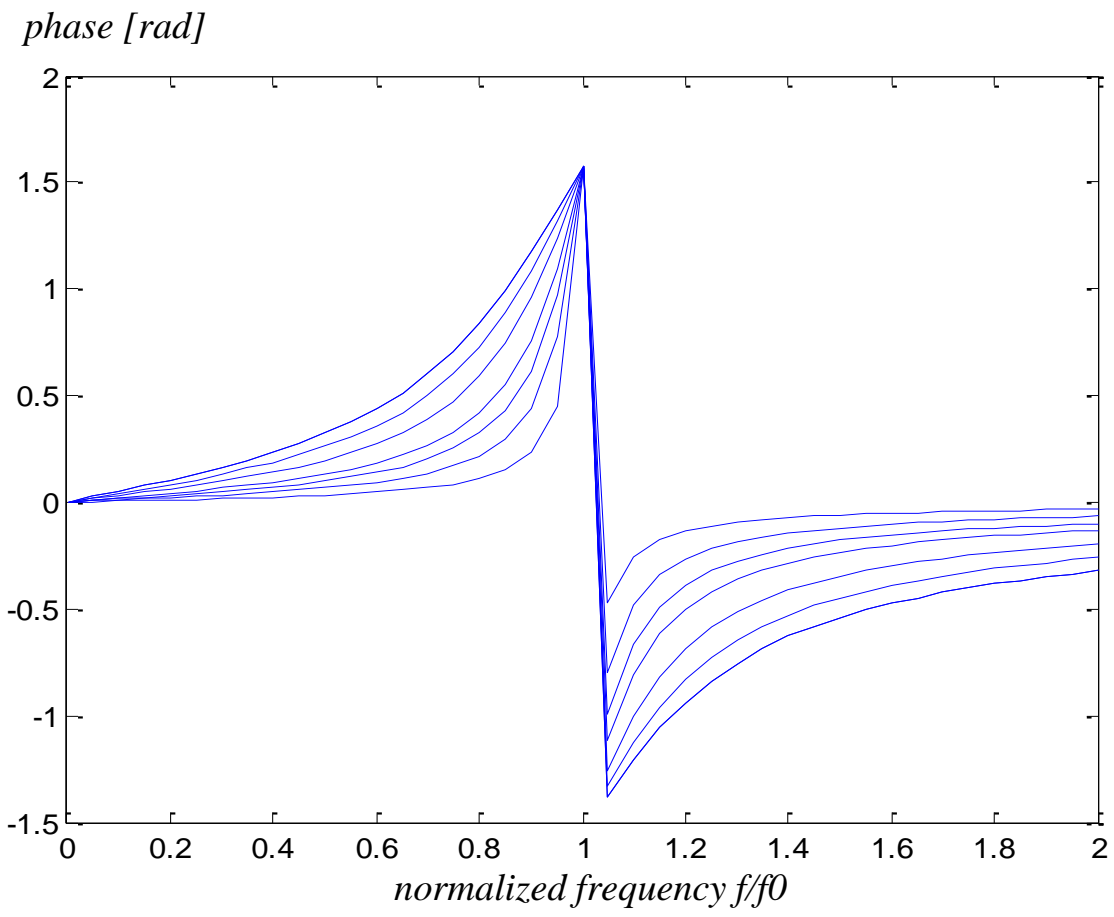

Fig. 2 Phase resonance curves generated for selected damping factors $0.05,0.1,0.15,0.2,0.3,0.4,0.5$ 
The analysis of synchronous blade vibration using linear sine fitting Analiza drgań synchronicznych topatek z wykorzystaniem liniowego dopasowania..

\section{Integral responses}

In turbomachinery the driving force $\mathrm{F}(\mathrm{t})=\mathrm{F}_{0} \cos (2 \pi f \mathrm{t})$ is often synchronous with the rotation:

$$
f=\operatorname{EO} f_{\mathrm{r}}
$$

$E O$ - engine order, $f$ - vibration frequency, $f_{r}$ - rotational frequency, equal rpm / 60

Tip deflection is measured synchronously with the excitation force, not only in the resonance:

$$
\text { EO } \alpha_{\mathrm{i}}=2 \pi f \mathrm{t}_{\mathrm{i}}
$$

$t_{i}$ - time of blade arrival to the sensor $i$, installed at the angle $\alpha_{i}$

This is why time can be eliminated from the oscillator solution:

$$
\mathrm{y}_{\mathrm{i}}=\mathrm{A} \cos \left[\mathrm{EO} \alpha_{\mathrm{i}}+\phi\right]
$$

For integral responses tip deflection $y_{i}(\omega)$ is time-independent speed function, related to angular sensor position (fig. 3). The integral response is synchronized with the measurement and belongs to low-frequency (static) component of the signal. The vibratory data that remains after subtracting the static deflection is considered as a non-integral response or noise.

During deceleration of the rotor, characteristic phase change (zigzag) is observed while passing a resonance. First generation single-sensor tip-timing systems located these zigzags to measure resonance speed and peak-peak amplitude. This technique, known as Zablotskiy method [14], works only for low-order, highamplitude resonances, lacks accuracy and is relatively difficult to be automated.

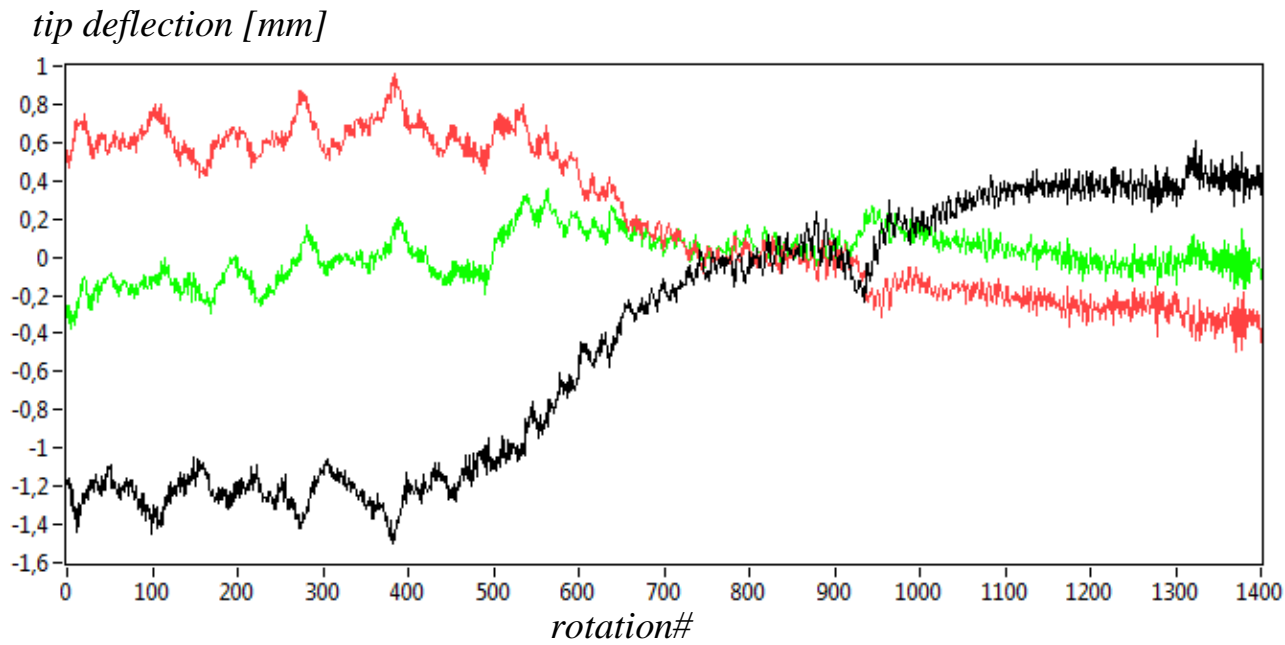

Fig. 3 Deflection of a blade's tip observed by three sensors during deceleration of the compressor. Three different integral responses visible at rotation No. 500-1000, 900 and 1300 
Approximate resonant frequencies and engine orders exciting blade vibratory modes are usually known from previous measurements and FEM analysis and presented on Campbell diagram. Using this information engine orders can be assumed to determine the frequency, amplitude and phase of the observed responses.

Integral responses can be characterized by linear least-square fitting using the equation of vibration in the form [5], [12], [16]:

$$
\mathrm{y}_{\mathrm{i}}=\mathrm{a} \sin \mathrm{EO} \alpha_{\mathrm{i}}+\mathrm{b} \cos \mathrm{EO} \alpha_{\mathrm{i}}+\mathrm{c}
$$

In this case the fitting is linear and well-conditioned when sensors are properly distributed on the circumference [5]. The amplitude and phase can be calculated from the fitting result $a$ and $b$.

The resonance frequency $\mathrm{f}_{0}$ is proportional to the rotational speed, at which the highest amplitude is observed and the phase crosses zero:

$$
\mathrm{f}_{0}=\mathrm{EO} \mathrm{n}_{0} / 60
$$

In practice, the problem of estimating the parameters of synchronous vibration is complicated, because higher-order responses have lower amplitudes and worse signal to noise ratio. Responses of different modes often occur at similar rotational speed (fig. 1). At least $2 \mathrm{~N}+2$ sensors are required to measure $\mathrm{N}$ simultaneous resonances.

\section{Least square fitting}

The method of least squares is one of the most common numerical techniques. The linear sine fitting functions available in Matlab and LabView are used below. Matlab even provides a special left-hand matrix division operator for this purpose: $\mathrm{a}=\mathrm{M} \backslash \mathrm{y}$ (mldivide). For a rectangular observation matrix $\mathrm{M}$, it finds the approximate solution $\mathrm{x}$ of linear system of equations $\mathrm{y}=\mathrm{M}$ a.

\section{Linear regression}

The following code performs the linear regression in MathScript, which is a clone of Matlab, available in LabView. Results of the function fit() and the left-hand division operator were compared (fig. 4). The observation matrix called „model” consists of the linear and constant term. Even for such a basic problem the fitting results slightly differ (for the benefit of the divisor operator).

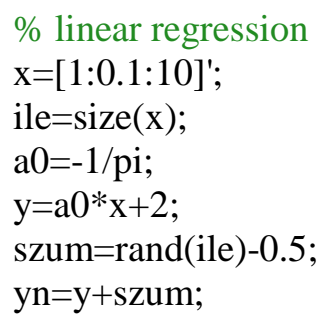


The analysis of synchronous blade vibration using linear sine fitting Analiza drgań synchronicznych topatek z wykorzystaniem liniowego dopasowania..

[a,yf,res]=fit(x,yn,'linear'); \% result a $=-0.3136 \mathrm{~b}=1.9808$
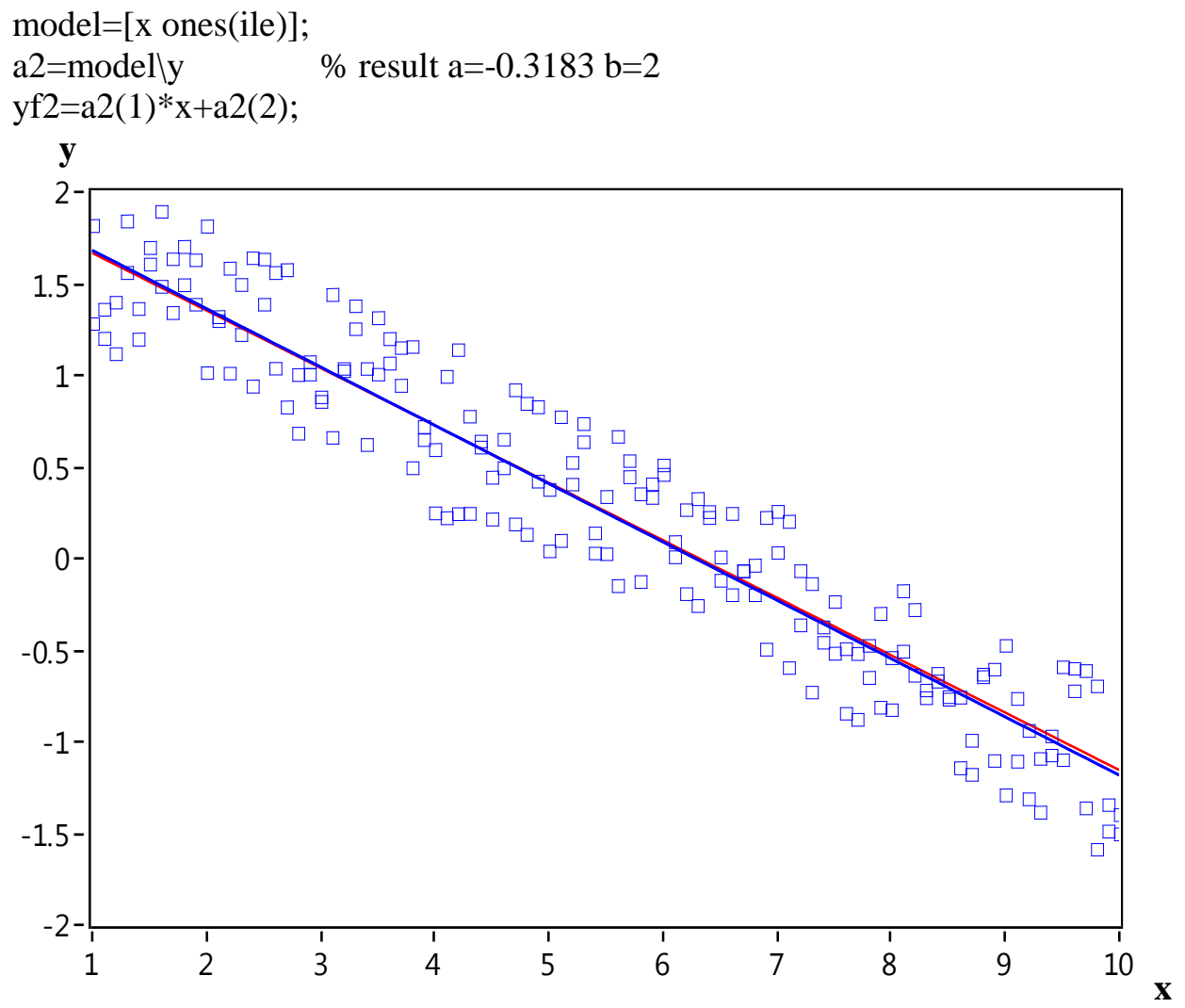

Fig. 4 Example of linear regression: red line - fit() function, blue line - left-hand division operator

\section{Sine fitting}

The following array of observation was created to perform sine fitting:

\section{model $=[\sin (x) \cos (x)$ ones $($ ile $)]$}

Linear matrix division was compared with a library function sqfit(). This time results were identical: [ -0.31831 .41422 ] - (fig. 5).

$\%$ The mysin function is defined by:

$\%$ function $[\mathrm{F}, \mathrm{df}]=\operatorname{mysin}(\mathrm{a}, \mathrm{x})$

$\% \mathrm{~F}=\mathrm{a}(1) * \sin (\mathrm{x})+\mathrm{a}(2) * \cos (\mathrm{x})+\mathrm{a}(3)$;

$\% \mathrm{df}=\operatorname{zeros}(0,0)$; 
clear all;

$\mathrm{x}=[1: 0.1: 10]^{\prime}$;

ile $=\operatorname{size}(x)$;

$\mathrm{a} 0=[-1 /$ pi $\operatorname{sqrt}(2) 2]$

$\mathrm{y}=\mathrm{mysin}(\mathrm{a} 0, \mathrm{x})$;

szum=rand(ile)-0.5;

yn=y+szum;

model $=[\sin (\mathrm{x}) \cos (\mathrm{x})$ ones(ile $)]$;

$\mathrm{a} 2=$ modelly

$\mathrm{yf} 2=\operatorname{mysin}(\mathrm{a} 2, \mathrm{x})$;

$\%$ In MATLAB $\backslash$ Optimization Toolbox use lsqcurvefit()

[a1, normres, resid] = 1sqfit('mysin', $[1,1,1], \mathrm{x}, \mathrm{y})$;

$\mathrm{yf} 1=\operatorname{mysin}(\mathrm{a} 1, \mathrm{x})$;

$\mathrm{y}$

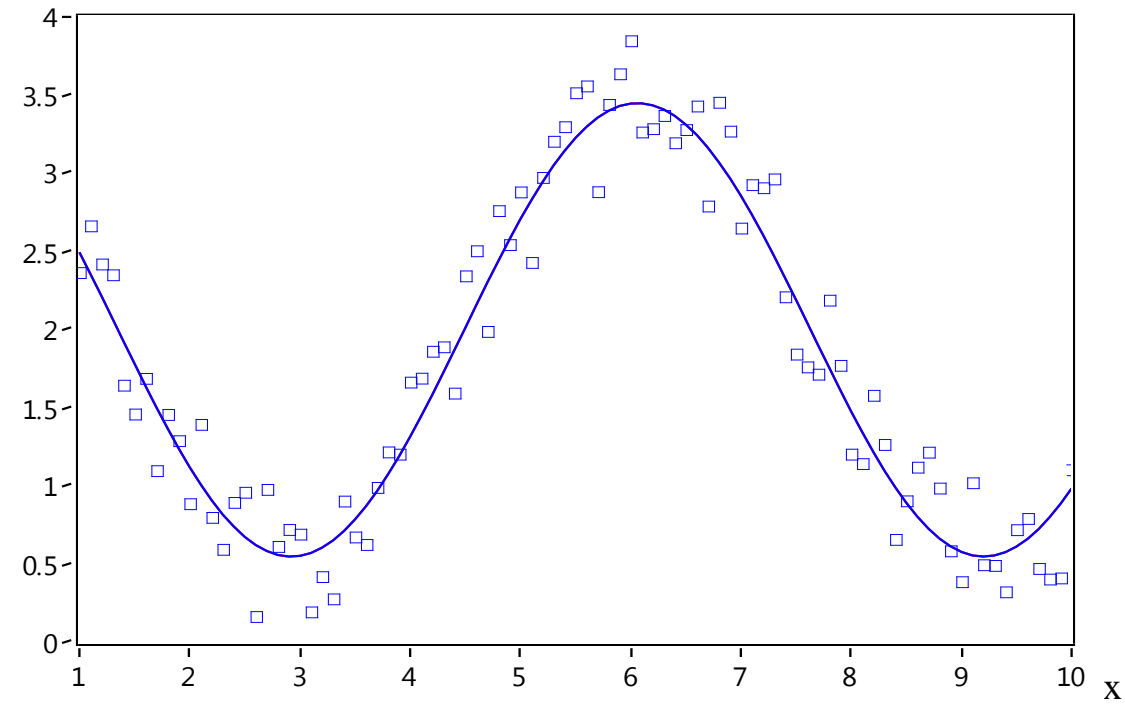

Fig. 5 Data fitted to the function $y=a \sin x+b \cos x+c$

\section{Numerical simulation}

The harmonic oscillator was used to simulate tip vibration of the compressor blade, which was passing through the first-mode resonance during the deceleration of the turbojet. The speed profile from a real test was loaded from the text file (fig. 6). We assumed that the natural frequency equals $500 \mathrm{~Hz}$, the engine order $\mathrm{EO}=2$, and damping factor 0.05 . 
The analysis of synchronous blade vibration using linear sine fitting Analiza drgań synchronicznych topatek z wykorzystaniem liniowego dopasowania..

Amplitude and phase was calculated for each rotation, assuming the engine order $\mathrm{EO}=2$. Then the three virtual sensors were placed on the circumference of the compressor. The sensor placement and the equation of rotation were used to calculate times of arrival, while neglecting the error coming from blade vibration. Blade tip displacement $\mathrm{y}(\mathrm{tt})$ was computed for these times, using the equation of the oscillator. In this way continues vibration signal was sampled by the virtual sensors like in the real BTT system.

The result shown in fig. 7 is incorrect, because the observations do not synchronize with the measurement. The arrival time tt depends on displacement of blade vibration, so it is difficult to calculate it directly. But for integral responses $\omega t=$ $\mathrm{EO} \alpha$ and this is why the oscillator equation can be used in the alternative form:

$$
y_{2}=A \cos (E O \alpha+\varphi)
$$

This time the sensors response $\mathrm{y}_{2}$ (fig. 8) is similar to the real test results and curves drown by Zablotskiy [14], [15].

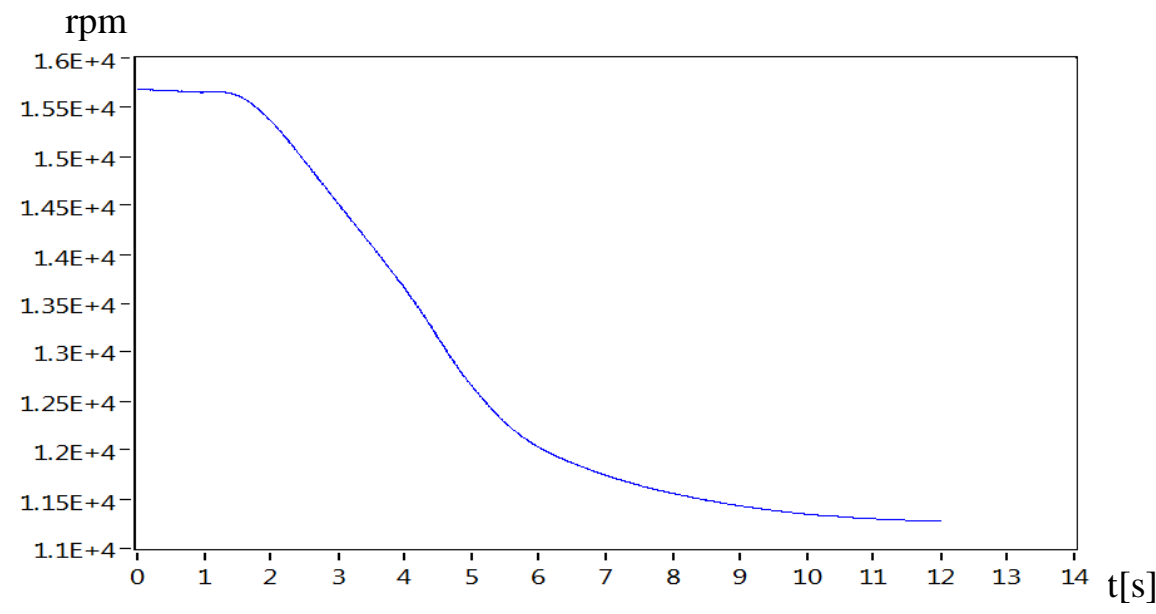

Fig. 6 Deceleration of the turbojet - rotational speed as a function of time

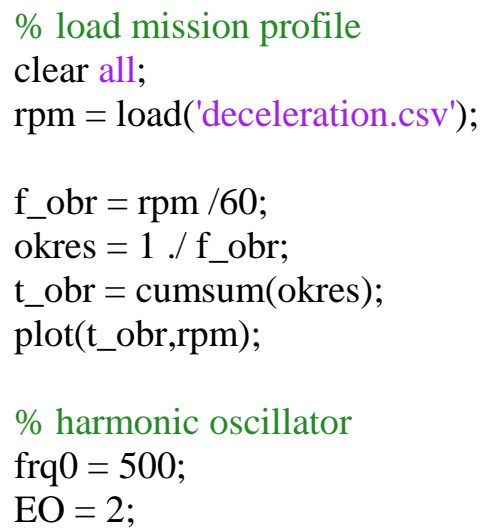




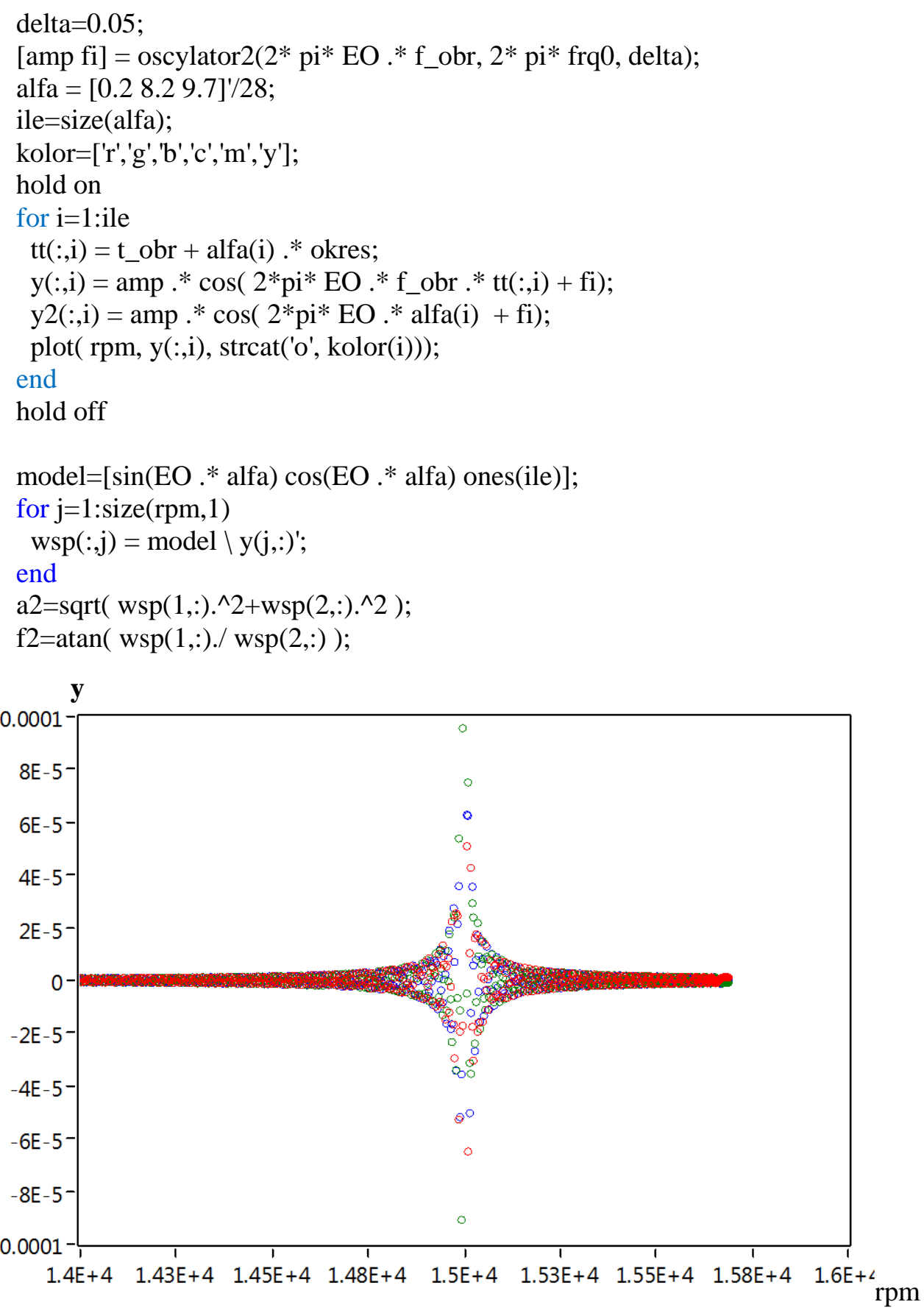

Fig. 7 Tip deflection y in a function of rotational speed, improperly sampled by 3 simulated sensors 
The analysis of synchronous blade vibration using linear sine fitting Analiza drgań synchronicznych topatek z wykorzystaniem liniowego dopasowania..

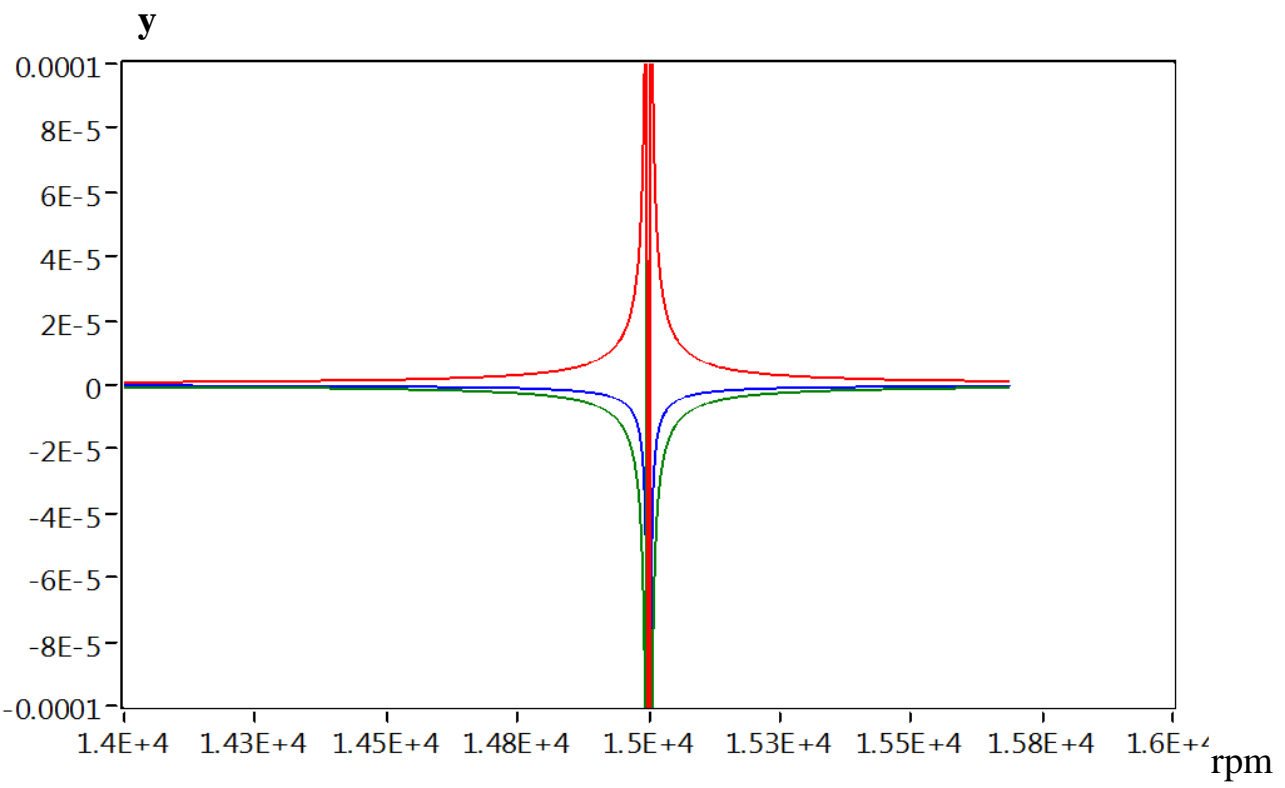

Fig. 8 Tip deflection y in a function of rotational speed observed by 3 simulated sensors

The final section of the script fits data from virtual sensors into the equation:

$$
\mathrm{y}=\mathrm{a} \sin \mathrm{EO} \alpha+\mathrm{b} \cos \mathrm{EO} \alpha+\mathrm{c}
$$

The amplitude (fig. 9) and phase were calculated from a and b using the following formulas:

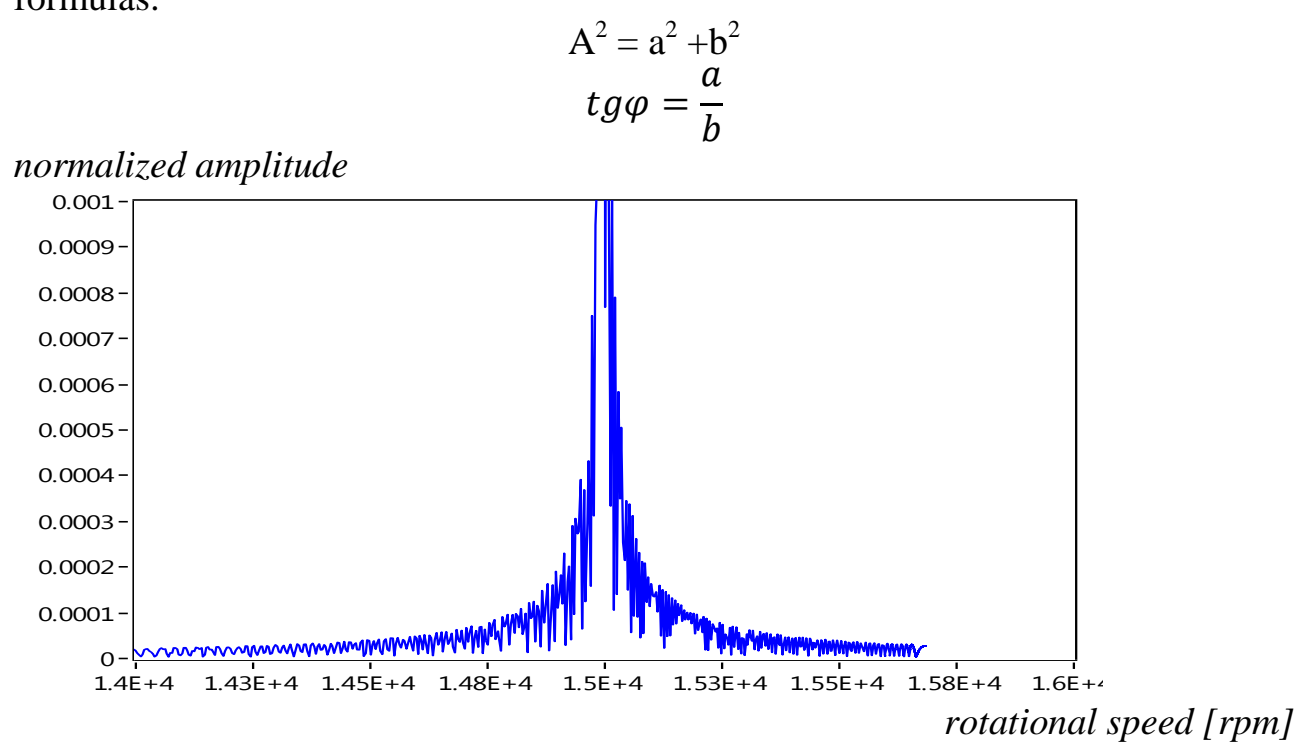

Fig. 9 Estimated amplitude in a function of rotational speed 


\section{Real test data}

The displacement of a selected blade was recorded with 3 inductive sensors during the same deceleration (fig. 6). The data included mainly M1EO2 response, which was coupled with some higher-order resonance at the rotation No. 950 (fig. 10). The static component of sensor's TOA signals should be adjusted to zero before fitting [13].

The amplitude shown by a single sensor is lower than the real resonance amplitude. This is why observation of several sensors should be combined and fitted into model to estimate the actual amplitude.

tip deflection $[\mathrm{mm}]$

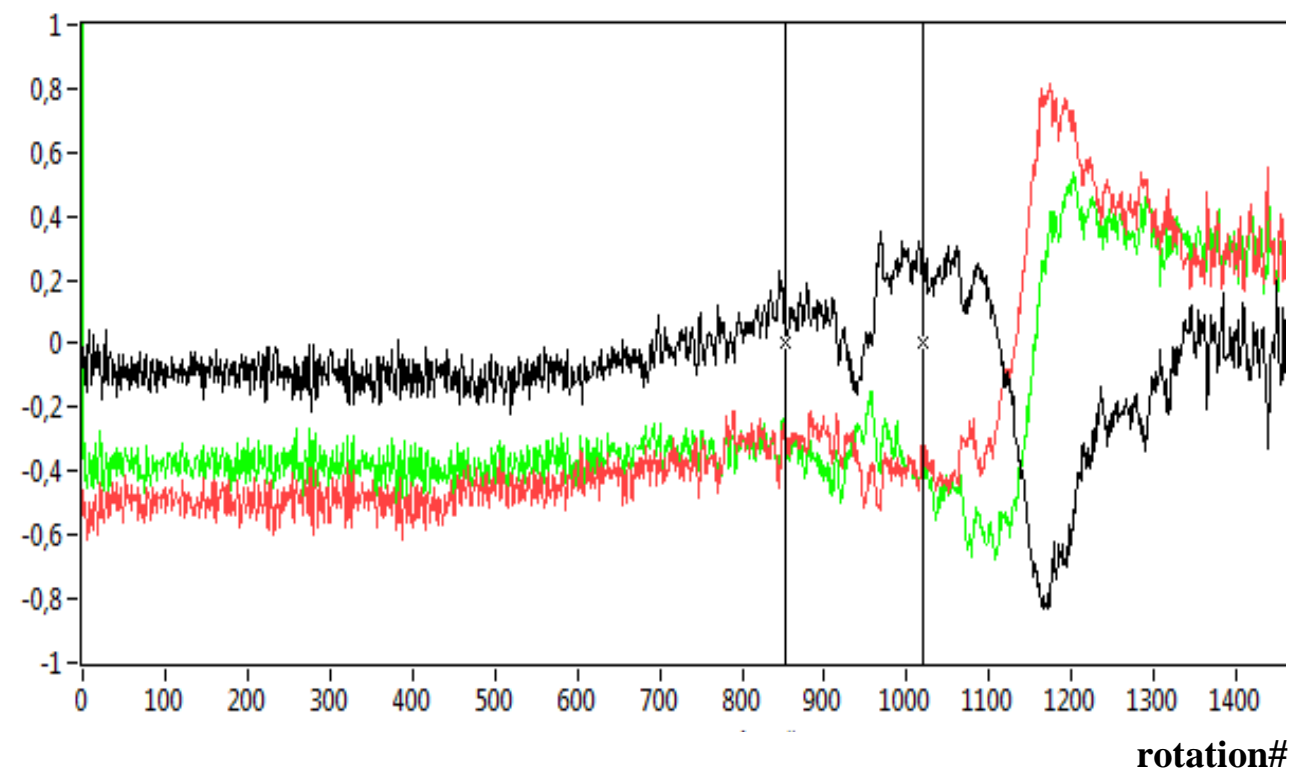

Fig. 10 Passing through two resonances - deflection of the blade's tip, observed by 3 sensors

\section{The identification of engine order}

The engine order EO of the resonance can be identified on XY plot, showing the trajectory of the blade tip, measured by a pair of sensors [1-4], [8]. In practice the application of Heath method is limited as ellipses are incomplete and deformed for coupled responses. Two resonances are presented: the low order resonance in fig.11 (M1EO2, rotations No 1150-1300) and the higher order in fig. 12 (rotations No 850-1020 in fig. 10). 
The analysis of synchronous blade vibration using linear sine fitting Analiza drgań synchronicznych topatek z wykorzystaniem liniowego dopasowania..

tip deflection - sensor 2

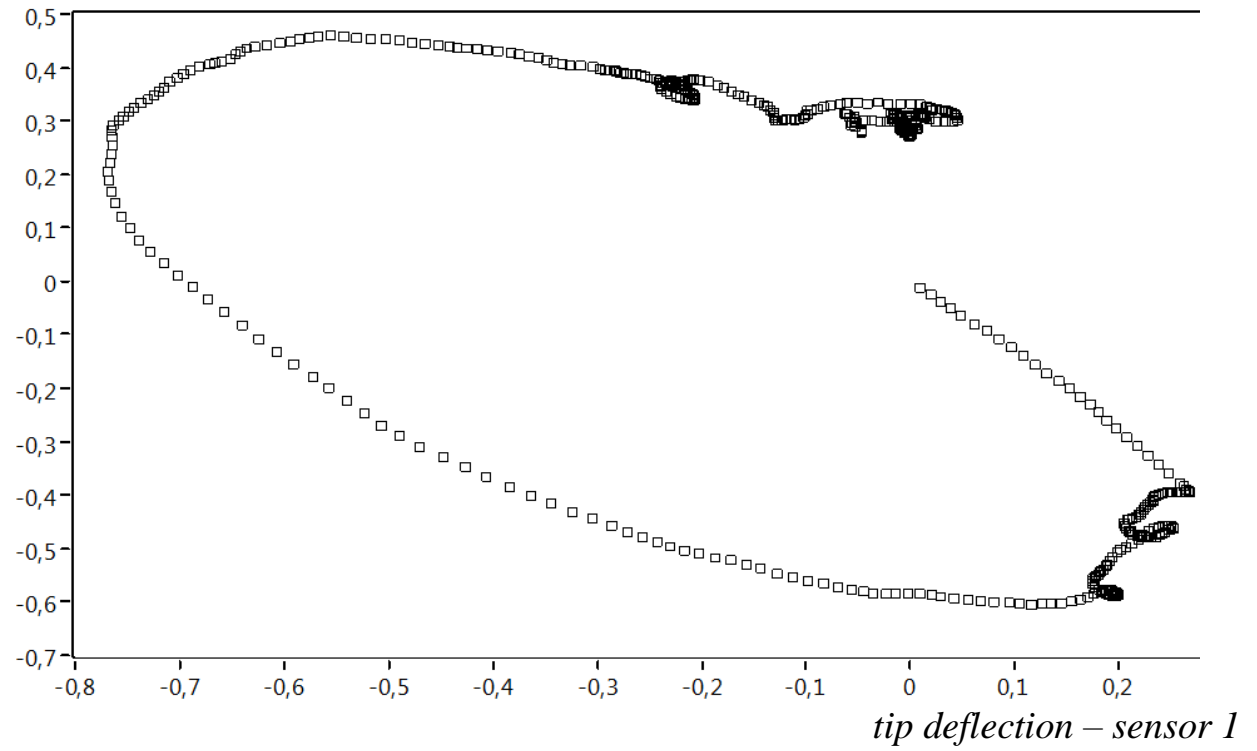

Fig. 11 Trajectory of blade-tip, low order resonance M1EO2, rotations No 1150-1300

tip deflection - sensor 2

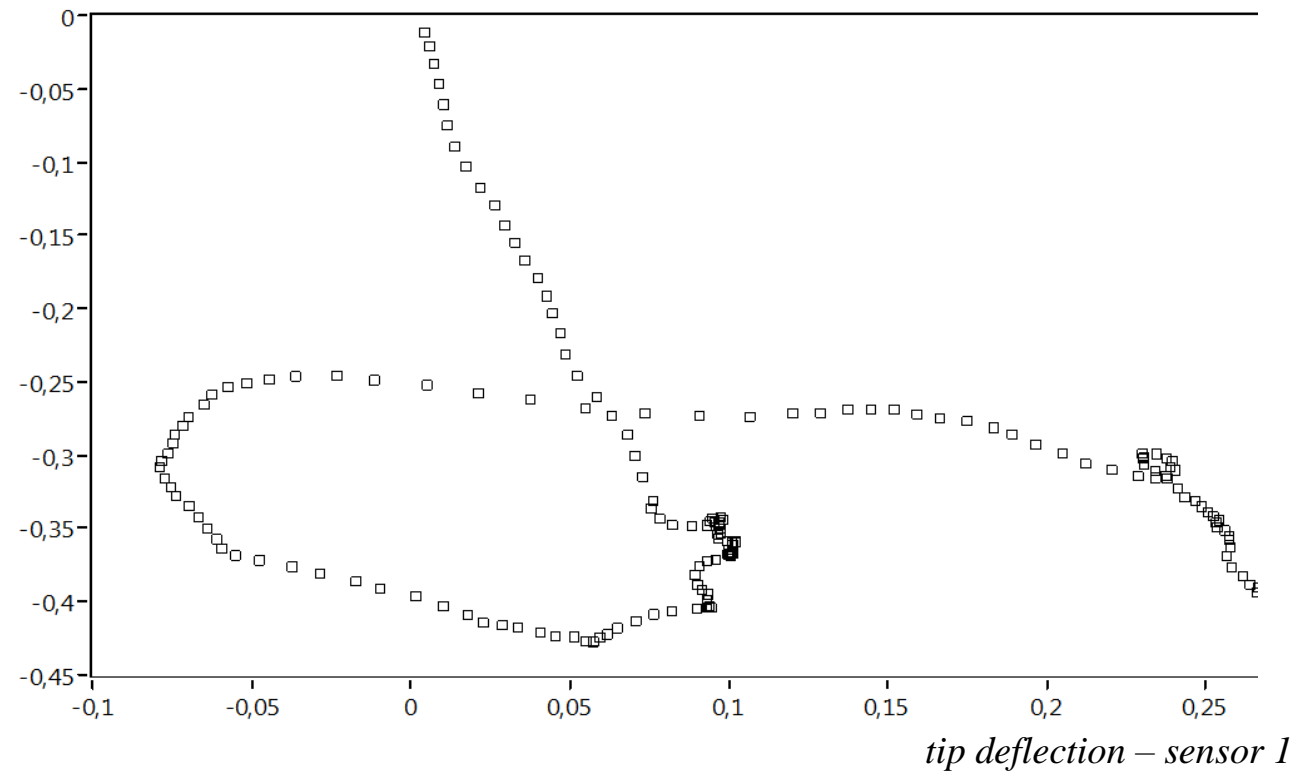

Fig. 12 Trajectory of blade-tip, higher order resonance M2EO7, rotations No 850-1020 


\section{Data fitting}

A sine fitting program was prepared in LabVIEW using the library function General LS Linear Fit (fig. 13), which requires observation matrix, similar to the one used previously in Matlab. The program can perform one fit for each rotation or alternatively combine a few rotations (ileObr parameter) into one vector, so the solution should be more accurate.

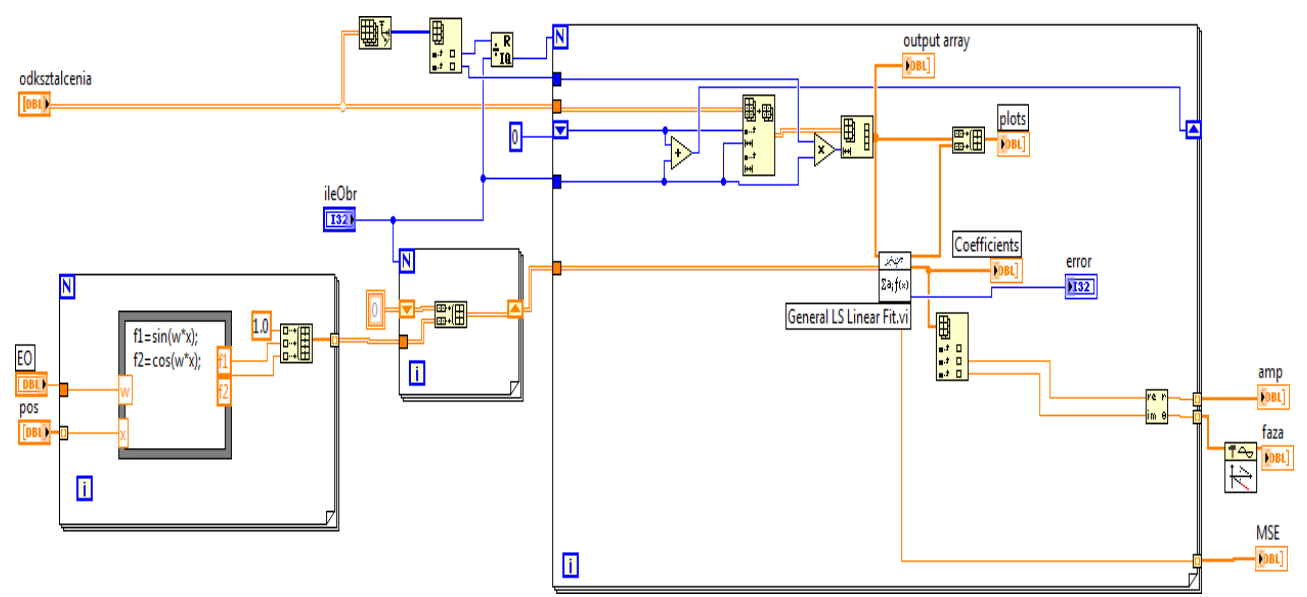

Fig.13 LabView procedure for linear sine fitting

After smoothing the source data (fig. 14) and taking 5 rotations per a fit, the following amplitude and phase sequences were obtained (fig. 15-16)

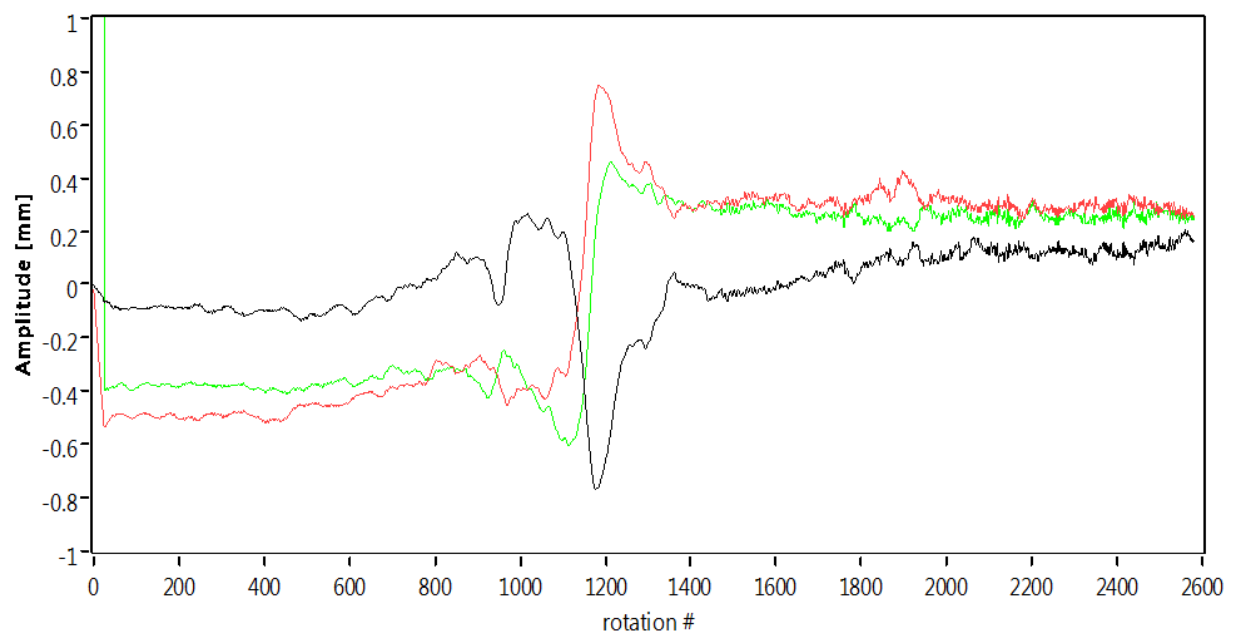

Fig.14 Passing through two resonances - smoothed deflection of the blade tip, observed by 3 sensors 
The analysis of synchronous blade vibration using linear sine fitting Analiza drgań synchronicznych topatek z wykorzystaniem liniowego dopasowania..

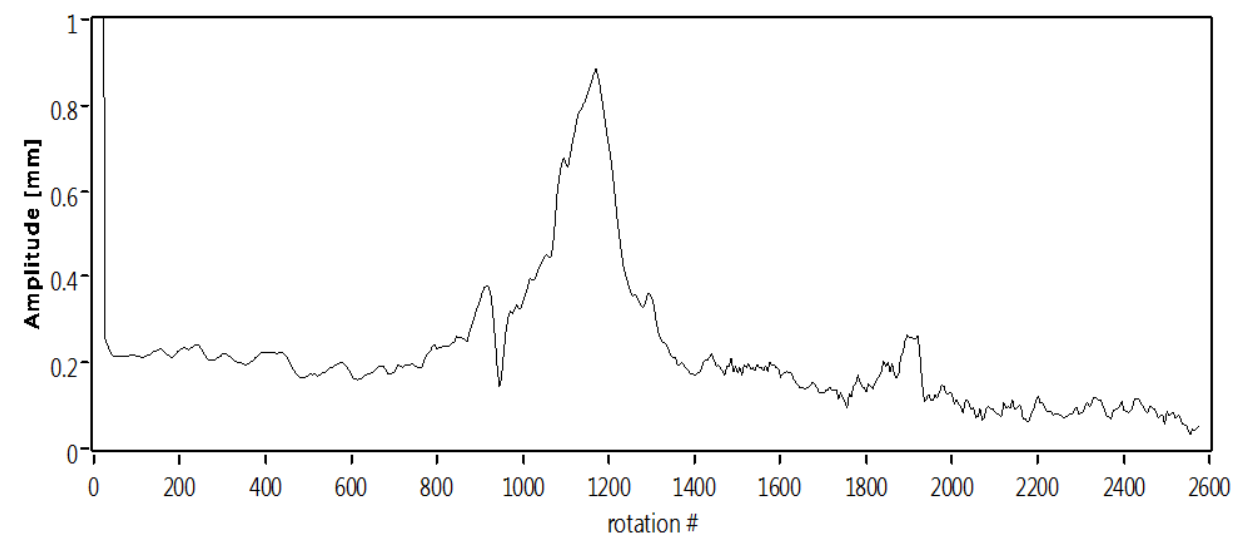

Fig. 15 Results of amplitude estimation

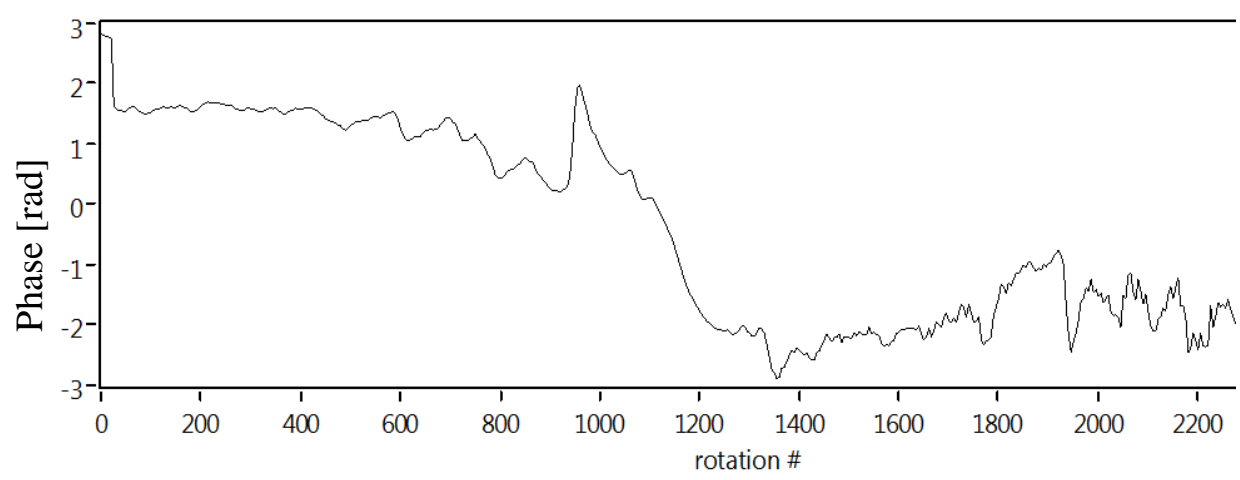

Fig. 16 Results of phase estimation

\section{Summary}

The driven oscillator model was used to simulate blade vibration observed by BTT system installed in the axial compressor. The method of least squares and linear sine fitting functions available in Matlab and LabView were applied to estimate vibration parameters. This technique is widely used to analyze integral responses in gas-turbine industry.

The project was financed by the Polish National Science Centre (NCN) under the decision DEC-2011/01/D/ST8/07612

\section{References}

[1] Grant K. Experimental Testing Of Some Tip-Timing Techniques, $1^{\text {st }}$ Evi-GTI Conference, Barcelona, 2004.

[2] Heath S. Imregun M. An improved single-parameter tip-timing method for turbomachinery blade vibration measurements using optical laser probes, International Journal of Mechanical Sciences, Vol. 38, №10, 1996, 1047-1058. 
[3] Heath S. A new technique for identifying synchronous resonances using tiptiming. ASME Journal of Engineering for Gas Turbines and Power. Vol. 122, No. 2. April 2000, 219-225.

[4] Heath S. Identification of resonant frequencies of vibration of rotating blades, US Patent 5,974,882, 1999.

[5] Jousselin O. Russhard P. A method for establishing the uncertainty levels for aeroengine blade tip amplitudes extracted from blade tip timing data, 10th International Conference on Vibrations in Rotating Machinery - IMECHE, London, 2012.

[6] Kaźmierczak K., Przysowa R. Standard Sine Fitting Algorithms Applied to Blade Tip Timing Data, Journal of Konbin, 2/2014.

[7] Kucher O.G. Kharton V.V. Laine J.P. Thouverez F. Criteria of Discrete Phase Control of Blade Working Condition, Aerospace Engineering and Technology, No 7(64), 2009.

[8] Osburn N. G. Implementation of a two probe tip-timing technique to determine compressor blade vibrations, Naval Postgraduate School Monterey CA, 2000.

[9] Overview of Curve Fitting Models and Methods in LabVIEW. National Instruments Tutorial. www.ni.com, 2009

[10] Russhard P. Blade Tip Timing - Frequently asked Questions, 57th ISA International Instrumentation Symposium (IIS) -Tip Timing Workshop, 2012.

[11] Russhard P. Method for analysing vibration in rotor blades, EP 2136189 B1 patent, 2009.

[12] Russhard P. Rotating blade analysis, GB2491632B patent, 2012.

[13] Russhard P. BTT Data Zeroing Techniques, MFPT and ISA's 59th International Instrumentation Symposium, 2013.

[14] Zablotskiy I., Korostelev Yu. Measurement of Resonance Vibrations of Turbine Blades With Elura Device, FTD-ID(RS)T-0861-78 (Originally published in Energomashinostroneniye, Nr. 2, February 1970)

[15] Zablotskiy I. Korostelev Yu. Sviblov L.B. Contactless Measuring of Vibrations in the Rotor Blades of Turbines, FTD AD-780 365-72 (Originally published as Beskontaktnye izmerenia kolebanij lopatok turbomaszin. Maszinostrojenije. Moskwa 1977).

[16] Zielinski M. Noncontact Blade Vibration and Tip Clearance Measurement on Aero Engine Comressors with BSSM, Tip-Timing and Tip-Clearance Problems in Turbomachinery, Von Karman Institute, 2007.

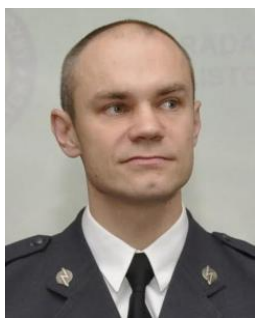

Radostaw Przvsowa PhD. Eng. has been working as a engineer and scientist supporting machine maintenance since 2002 (in the position of the Assistant Professor at the moment). He is also familiar with research management and commercialization and has remarkable programming skills, including obiect oriented programming, digital signal processing and data mining. He specializes in Blade Tip-timing, which is a non-contact vibration measurement method, involving processing of aliased displacement signals. 